\title{
Conservation status of an endangered annual fish Hypsolebias antenori (Rivulidae) from Northeastern Brazil
}

\author{
Nascimento, WS. ${ }^{a, b *}$, Yamamoto, ME. ${ }^{b}$, Chellappa, NT. ${ }^{c}$, Rocha, O. ${ }^{d}$ and Chellappa, $S .^{b}$ \\ ${ }^{a}$ Núcleo de Estudos em Pesca e Aquicultura - NEPA, Universidade Federal do Amapá - UNIFAP, \\ Rod. Juscelino Kubitschek, Km 02, Jardim Marco Zero, CEP 68903-419, Macapá, AP, Brazil \\ 'Programa de Pós-Graduação em Psicobiologia, Centro de Biociências, Universidade Federal do Rio Grande \\ do Norte - UFRN, Av. Salgado Filho, 3000, Lagoa Nova, CEP 59072-970, Natal, RN, Brazil \\ 'Departamento de Oceanografia e Limnologia, Centro de Biociências, Universidade Federal do Rio Grande \\ do Norte - UFRN, Via Costeira Senador Dinarte Medeiros Mariz, Mãe Luiza, s/n, CEP 59.014-002, Natal, RN, Brazil \\ ${ }^{d}$ Departamento de Ecologia e Biologia Evolutiva, Centro de Ciências Biológicas e da Saúde, Universidade Federal \\ de São Carlos - UFSCar, Rod. Washington Luis, Km 235, Monjolinho, CEP-13565-905, São Carlos, SP, Brazil \\ *e-mail: wallacesn@unifap.br
}

Received: October 15, 2013 - Accepted: November 13, 2013 - Distributed: May 31, 2015

(With 4 Figures)

\begin{abstract}
This work presents information regarding the biology and state of conservation of an endangered annual fish Hypsolebias antenori. Fish were captured from small seasonal pools located in Northeastern Brazil. The total body length, body mass, sex ratio, first sexual maturity were investigated. The sampled population showed sexual dimorphism. There was a predominance of females $(60 \%)$ over males $(40 \%)$ with a sex ratio of $1: 1.4$ and males were bigger and heavier than the females. Amplitude of total length of males ranged from 2.6 to $7.1 \mathrm{~cm}(4.1 \pm 1.15)$ and that of females from 2.2 to $5.4 \mathrm{~cm}(3.6 \pm 0.9)$. Amplitude of body mass of males varied from 0.25 to $7 \mathrm{~g}(1.3 \mathrm{~g} \pm 1.4)$ and that of females from 0.12 to $2.1 \mathrm{~g}(0.7 \mathrm{~g} \pm 0.5)$. The total weight-length equation of males was $\mathrm{Wt}=0.0108 \mathrm{Lt} 3.172$ with $\mathrm{r}=0.9826$ and of females was $\mathrm{Wt}=0.0122 \mathrm{Lt} 3.0114$ with $\mathrm{r}=0.9608$. Females attained first sexual maturity at $3.2 \mathrm{~cm}( \pm 0.25)$ total length and males at $3.3 \mathrm{~cm}( \pm 0.08)$ total length. All temporary pools surveyed in Northeastern Brazil were in a high degree of degradation, suffering due to anthropogenic action. Reduced rainfall resulting from global climate change prevents the filling up of these pools, thus preventing the completion of the reproductive cycle of annual fishes. One factor hindering development of conservation strategies is limited literature on biology and conservation status of annual fishes. There is a need for conservation measures to protect annual fish populations, especially creation of protected areas in the Brazilian semiarid region.
\end{abstract}

Keywords: annual fishes, Rivulidae, temporary pools, biology, conservation.

\section{Status de conservação de Hypsolebias antenori (Rivulidae) um peixe anual ameaçado do Nordeste brasileiro}

\begin{abstract}
Resumo
Este trabalho apresenta informações sobre a biologia e estado de conservação de Hypsolebias antenori, um peixe anual ameaçado. Os peixes foram capturados em pequenas poças temporárias localizadas no Nordeste do Brasil. O comprimento total, peso total, proporção sexual e a primeira maturação sexual foram investigados. A espécie em estudo apresentou dimorfismo sexual bem evidente. Houve um predomínio de fêmeas (60\%) sobre os machos (40\%), com uma razão sexual de 1M: 1,4F. Os machos foram significativamente maiores e mais pesados do que as fêmeas. A amplitude do comprimento total dos machos variou de 2,6 a 7,1 centímetros $(4,1 \pm 1,15)$ e as fêmeas de 2,2 a 5,4 centímetros $(3,6 \pm 0,9)$. A amplitude de peso dos machos variou de 0,25 a $7 \mathrm{~g}(1,4 \pm 1,3 \mathrm{~g})$, enquanto que as fêmeas de 0,12 a $2,1 \mathrm{~g}(0,5 \pm 0,7 \mathrm{~g})$. A equação da relação peso total/comprimento dos machos foi $\mathrm{Wt}=0.0108 \mathrm{Lt}^{3.172} \mathrm{com}$ $\mathrm{r}=0,9826$ e para fêmeas foi $\mathrm{Wt}=0.0122 \mathrm{Lt}^{3.0114} \mathrm{com} \mathrm{r}=0,9608$. As fêmeas alcançaram a primeira maturação sexual com 3,2 cm $( \pm 0,25)$ de comprimento total e os machos com 3,3 centímetros $( \pm 0,08)$ de comprimento total. Todas as poças temporárias amostradas neste trabalho estavam em um alto grau de degradação, principalmente devido à ação antrópica. Observamos que diminuição das chuvas e a desertificação decorrente das mudanças climáticas globais que também são alarmantes e poderão impedir a conclusão do ciclo reprodutivo dos peixes anuais. As informações sobre a biologia e o estado de conservação dos peixes anuais ainda são limitadas, portanto há uma grande necessidade estudos e de medidas de conservação para proteger as populações de peixes anuais, entre elas especialmente a criação de áreas proteção nos ambientes aquáticos efêmeros do semiárido brasileiro.
\end{abstract}

Palavras-chave: peixe anual, Rivulidae, poças temporárias, biologia, conservação. 


\section{Introduction}

The Caatinga biome of Brazil is considered to be one of the 37 Wilderness Areas of the World, and it plays an important role in the maintenance of regional macro-ecological process, as well as indirectly supporting regions with diversity and endemism in Brazil (Leite and Machado, 2010.) Northeastern Brazil has distinctive scrub vegetation referred to as "Caatinga", consisting of xerophytic low thorny bushes adapted to the semiarid climate, which covers over $10 \%$ of the Brazilian territory. It is located between $3^{\circ} \mathrm{S} 45^{\circ} \mathrm{W}$ and $17^{\circ} \mathrm{S} 35^{\circ} \mathrm{W}$, extending across eight administrative states of Brazil: Piauí, Ceará, Rio Grande do Norte, Paraiba, Pernambuco, Alagoas, Sergipe, Bahia, and parts of Minas Gerais (Leal et al., 2003).

The semiarid Caatinga biome of Northeastern Brazil is characterized by short spells of rain interspersed with frequent droughts. The hydrographic network of this region is seasonal and modest when compared to other Brazilian regions. The seasonality of the freshwater ecosystems is due to recurrence of extended drought, irregular rainfall, high temperatures and an elevated rate of water evaporation (Chellappa et al., 2006; Chellappa et al., 2009). This region receives almost $750 \mathrm{~mm}$ of annual rainfall and has an average annual temperature of $26^{\circ} \mathrm{C}$ throughout most of the region (Silva, 2004) and encompasses more than $750,000 \mathrm{~km}^{2}$ in the northeast region of Brazil being the only Brazilian biome that is situated entirely inside the Brazilian territory (Leal et al., 2005). The fish communities that occur in the freshwater ecosystems of the semiarid region of Brazil, exhibit a high degree of Neotropical native species, and are important areas for conservation of fish species (Rosa et al., 2005; Chellappa et al., 2011; Nascimento et al., 2011).

The family Rivulidae is one of the largest families of freshwater fishes of the Neotropical Region. It is a diverse group of annual fish, most popularly known as "killifish", with about 350 valid species which occur from South of Florida, in the United States, to the Northeast of Argentina (Costa, 2011). Brazil has the greatest diversity of annual fish, with about 200 species, of which $60 \%$ belongs to family Rivulidae (Costa, 2008). Currently the family Rivulidae is represented by 30 genera (Fricke and Eschmeyer, 2012). Despite the richness of killifishes, this family is considered the most endangered of all the groups of fish in Brazil (Rosa and Lima, 2008).

The annual fishes complete their life cycle in temporary pools and when the water pools dry out during the dry season, the entire population dies from desiccation. These temporary pools are environments that have large fluctuations in temperature, level of dissolved oxygen concentration and volume of water. To survive in these extreme conditions, the fish eggs that are deposited in the sediment of the pools go through diapause stages, during which time the embryonic development becomes temporarily arrested. With the onset of the next rainy season, the eggs hatch and a new generation is formed (Wourms, 1972; Errea and Danulat, 2001). These temporary environments have suffered major human impacts such as siltation, deforestation, pollution and drainage.

There is very limited literature on the biology and conservation status of endemic annual fish Hypsolebias antenori (Costa, 2006). This species was first collected in 1945 in Ceará from Northeastern Brazil and was described in the genus Simpsonichthys (Costa, 2002) and in 2006 a new taxonomic revision of the genus found this species in the subgenus Hypsolebias (Costa, 2006). This paper provides information on some biological aspects of this rare annual fish (Rivulidae), and evaluates its conservation status.

$H$. antenori spawns during the rainy season presenting $r$ reproductive strategy. The following questions were addressed: Does sexual dimorphism exist in the males and females? What is the biggest body size attained by males and females of this species? What type of growth do they show? At what size do they attain first sexual maturity?

\section{Material and Methods}

The capture of fish was authorized by ICMBIO-MMA (Chico Mendes Institute for Biodiversity Conservation of the Brazilian Ministry of Enviroment) / SISBIO (Authorization system and biodiversity information), with the authorization number 27451. Fish were collected in temporary pools located in public place outside the conservation area.

Extensive fish surveys were carried out in regions adjoining various hydrographic basins in the States of Rio Grande do Norte and Ceará, during 2011 to 2013. $H$. antenori was captured in August, 2011 and again in May, 2013, when the temporary pools were full during the rainy season of the region. Due to the failure of rainfall, no temporary pools were formed during 2012, which year had the worst extended dry season registered over past 50 years (WMO, 2012). The temporary pools were located between $04^{\circ} 57^{\prime} 39.8^{\prime \prime} \mathrm{S}$ and $37^{\circ} 54^{\prime} 26.2^{\prime \prime} \mathrm{W}$. The approximate diameter and depth of each pool was measured.

The climate of this region is semiarid, with an average annual rainfall of $829.8 \mathrm{~mm}$. The water temperature $\left({ }^{\circ} \mathrm{C}\right)$, concentration of dissolved oxygen $\left(\mathrm{mgL}^{-1}\right), \mathrm{pH}$ and electrical conductivity $\left(\mu \mathrm{Scm}^{-1}\right)$ of the temporary pools were registered in situ, using specific probes of the multiparameter kit WTW Multi 340i. The kit was calibrated before every collection. Fish were captured utilizing small hand trawl nets $(50 \times 150 \mathrm{~cm})$ and sieves $(60 \times 60 \mathrm{~cm})$ of $2 \mathrm{~mm}$ mesh size. Fish specimens captured were transported to the laboratory under oxygenation. Each fish was numbered, measured (total length $\mathrm{Lt} \pm 1 \mathrm{~mm}$ ), and weighed (total weight $\mathrm{Wt} \pm 1 \mathrm{~g})$. The taxonomical identification of the fish species was verified and confirmed (Costa, 2006).

The sex ratio was established by the ratio between the number of males and females during the study period. The brightly colored males with well developed dorsal and anal fins were easily separated from the females.

Body size at first gonadal maturity $\left(L_{50}\right)$ where $50 \%$ of the individuals exhibited maturing gonads was estimated from the relative frequency distribution of adult males and females, using their total length classes (mean \pm SD). 
Body sizes of the males and females (in total length and body mass) were estimated from the relative frequency distribution, using their standard length and body mass classes (mean $\pm \mathrm{SD}$ ). The length-weight relationships were estimated using the equation $\mathrm{Wt}=\mathrm{a} \cdot \mathrm{Lt}^{\mathrm{b}}$ (Froese, 2006). The value of correlation coefficient (r) was estimated for evaluation of empirical points adhesion for the calculated curve.

Data were analyzed using the software Statistic 7.0 and Excel 2010 for Windows and at a significance level of 5\%. Normality of data was checked using Kolmorogov-Smirnov test. To verify the differences in means of standard length and total weight between males and females, the Student t test was used. The G test was applied in order to test the possible differences in sex ratio established.

To compare the conservation status of $H$. antenori in the semiarid region of Brazil, published scientific works were consulted besides personal observations effected during the three year study period.

\section{Results and Discussion}

The temporary pools checked during the study period had a mean diameter of $1.55 \mathrm{~m}( \pm 0.57)$, with mean depth of $19.5 \mathrm{~cm}( \pm 13.4)$. In relation to the physico-chemical parameters of the pools, the mean water temperature was $30 \mathrm{C}^{\circ}( \pm 2.82)$, the mean value of the concentration of dissolved oxygen was $4 \mathrm{mgL}^{-1}( \pm 0.14)$, mean $\mathrm{pH}$ was $6.3( \pm 0.77)$ and the mean electrical conductivity was $140 \mu \mathrm{Scm}^{-1}( \pm 1.41)$. These values are different from those found for other aquatic environments of the region (Chellappa et al., 2008; Nascimento et al., 2012), but are similar to those found in temporary pools of southern Brazil where annual fish were captured (Volcan et al., 2011).

The only annual fish captured was H. antenori $(\mathrm{n}=147)$. This species exhibits sexual dimorphism, where males show a striking bluish-green body colouration with white dots, with a clear light pink ventral part. The fins of males are well developed than the females. The anal fin of the male is reddish orange with a black border and several white spots (Figure 1a). The female has a predominantly light grey body, and a pale belly with several black spots (Figure 1b). Sexual dimorphism is an important characteristic in annual fishes, which suggests that sexual selection may play a key role in the differentiation, isolation, speciation and evolution of this group of fish (Berois et al., 2012).

There was a predominance of females $(n=87 ; 60 \%)$ over the males ( $\mathrm{n}=60 ; 40 \%)$. The sex ratio was $1 \mathrm{M}: 1.4 \mathrm{~F}$, with a significant difference $(\mathrm{G}=4.02 ; \mathrm{P}<0.05)$. Several factors influence the determination of the sex ratio in fish, such as, mortality, growth, behavior and environmental variations which act differently on the sexes, altering the sex ratio in various stages of development. The expected sex ratio for the natural environment is generally 1M:1F (Nascimento et al., 2012; Araújo et al., 2012). The greater number of females in this study may be related to the territorial behavior of males. The aggressive behaviour between males was observed for other species of annual fish (Arenzon et al., 1999; Shibatta, 2006), where the male defends a territory and many females are free to visit these territories. Polygynous species generally exhibit territorial behaviour (Magurran and Garcia, 2000). The environmental factors could also affect the fish sex ratio, including hypoxia, which affects both sexual development, differentiation and sex ratio (Shang et al., 2006; Wu, 2009). Among the environmental factors, temperature has the most profound influence on the differentiation of sex (Sfakianakis et al., 2012). Hypoxia and temperature are two major environmental factors that vary and influence the fish of temporary pools. It is very important to investigate as to how these factors act in differentiation and sexual development of annual fish.

Amplitude of total length of males ranged from 2.6 to $7.1 \mathrm{~cm}(4.1 \pm 1.15)$ and that of females from 2.2 to $5.4 \mathrm{~cm}$ (3.6 \pm 0.9$)$. A higher frequency of males was observed in class of 3 to $4 \mathrm{~cm}$ total length. The females had a large number of individuals in the class of $3 \mathrm{a} 4 \mathrm{~cm}$ (Figure 2). The males attained larger lengths than the females ( $\mathrm{t}$ test $=-3.154 ; \mathrm{p}=0.002$ ).

Amplitude of body mass of males varied from 0.25 to $7 \mathrm{~g}(1.3 \mathrm{~g} \pm 1.4)$ and that of females from 0.12 to $2.1 \mathrm{~g}$ $(0.7 \mathrm{~g} \pm 0.5)$. The males had a higher frequency in the class of 0 to $1 \mathrm{~g}$, and a higher frequency of females was in the class of 0 to $1 \mathrm{~g}$ (Figure 2 ). The males attained significantly higher body weights than females $(t=-3.902 ; \mathrm{p}=0.001)$. Larger males generally have an advantage in choosing the female to spawn, win fights over territories and have better quality spawning territories (Cacho et al., 2006).

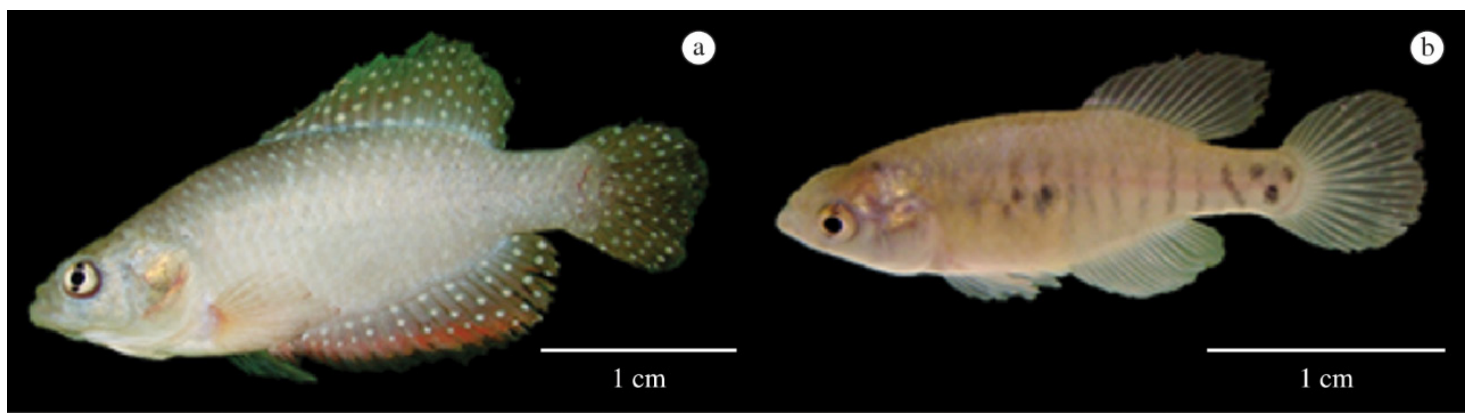

Figure 1. Species of study, Hypsolebias antenori (a) Males and (b) Females. 
The total weight-length equation of males was $\mathrm{Wt}=0.0108 \mathrm{Lt}^{3.172}$ with $\mathrm{r}=0.9826$ and of females was $\mathrm{Wt}=0.0122 \mathrm{Lt}^{3.0114}$ with $\mathrm{r}=0.9608$ (Figure 3). Females attained first sexual maturity at $3.2 \mathrm{~cm}( \pm 0.25)$ total length and males at $3.3 \mathrm{~cm}( \pm 0.08)$ total length. In the case of $H$. antenori, the values of $\theta$ for males (3.172) and females (3.0114), suggest that males show positively allometric growth, indicating more weight gain than increment in length whereas females showed isometric growth, an increase in all dimensions of the body in the same proportion. The parameter $\theta$ could vary for fish of different habitats, with varying environmental conditions and different nutritional status, sex, or the phase of growth. Thus, the ratio between the total weight and total length can be seen as a differential character for small taxonomic units as the morphometric relationships (Jobling, 2008).

The estimated total body length at first gonadal maturity $\left(\mathrm{L}_{50}\right)$ of $\mathrm{H}$. antenori males was $3.3 \mathrm{~cm}( \pm 0.08)$ and that of females was $3.2 \mathrm{~cm}( \pm 0.25)$ (Figure 4$). H$. antenori attained first gonadal maturity at small body size due to its short life in unpredictable environments, such as the seasonal pools.

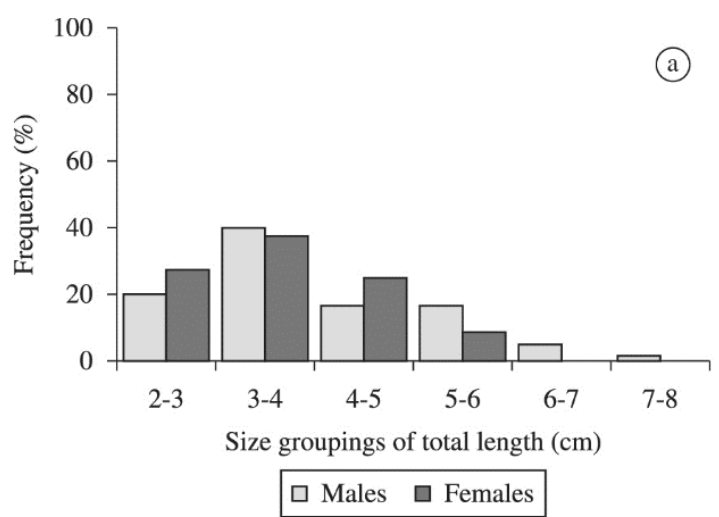

\subsection{Status of conservation}

There are 24 species of annual fish which were registered in the Brazilian semiarid region (Costa, 2002). They all belong to the family Ruvulidae, with 12 species of the genus Simpsonichthys, 11 of Cynelobias and one of Rivulus, and all are endemic (Costa, 2002; Rosa et al., 2005).

Annual fishes are concentrated in the great diversity of endangered fish, whose fragile habitat is a critical factor in their conservation (Rosa and Lima, 2008; Costa, 2012). Endemic fish species suffer a high probability of extinction because of their small size and low abundance (Gaston, 1998). In Brazil, 134 fishes are threatened with extinction, of which 55 are Cyprinodontiformes of the family Rivulidae. Among these, 25 species are considered vulnerable, 16 are endangered and 14 are critically endangered (Agostinho et al., 2005). In the state of Rio Grande do Sul, 26 species of Rivulidae were registered, all of which are threatened with extinction (Reis et al., 2003). The present work considers $H$. antenori as an endangered annual fish species in the Brazilian semiarid region.

Populations of $H$. antenori are threatened by urbanization, agricultural and ceramic activities. The study area of this

Figure 2. Class distribution of (a) total length (b) body mass for male and female Hypsolebias antenori.

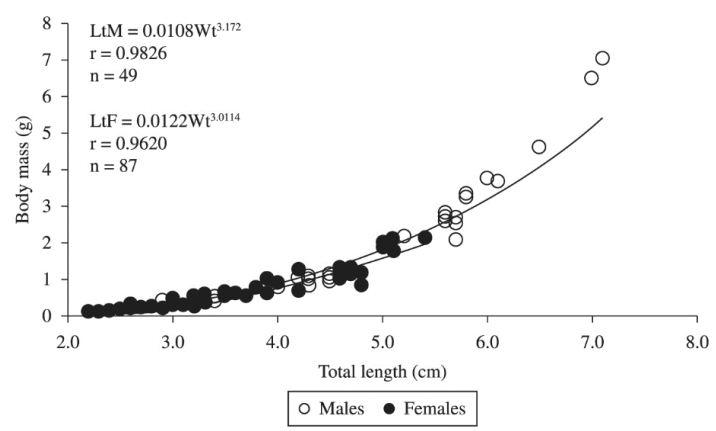

Figure 3. Length-Weight relationship for males and females of Hypsolebias antenori distributed in individual empirical points.

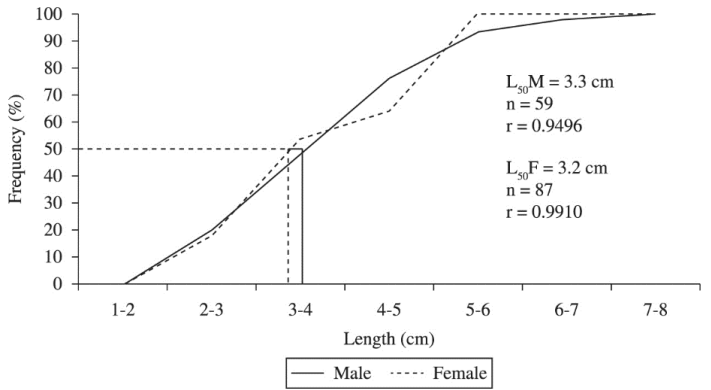

Figure 4. Relative frequency of first gonadal maturation $\left(\mathrm{L}_{50}\right)$ of (a) males and () females Hypsolebias antenori. The inserted lines represent the estimated size range where $50 \%$ of the fish were were mature. 
work, accounts for about $70 \%$ of all activities of ceramic production. Environmental degradation due to clay extraction for the production of bricks and tiles poses a big problem. In addition, there are the negative effects caused by erosion and consequent destruction of the soil, which leads to loss of habitats and biodiversity, and destroys the natural landscape (Parahyba et al., 2000; Pinheiro, 2002). The construction of many small dams in the northeast of Brazil poses yet another threat, since flooding several areas including destruction of temporary pools destroys the habitats of annual fish.

Fruit farming corresponds to the fastest growing activity in the northeast of Brazil, highlighted by the large agricultural production and crop diversity. There is a large increase in the use of pesticides and agrotoxins that remain in the environment, posing risks. The study area of this work, the Chapada do Apodi between the state of Ceará and Rio Grande do Norte, is a major area of horticulture. In this region eight kinds of pesticides were found, with high potential for contamination associated with soil, and 13 high potential pesticides for contamination by dissolving in water (Milhome et al., 2009).

Annual fish of Brazilian semiarid region have suffered from the change of the rainfall regime caused by global climate change. The natural environmental phenomena El Nino and La Nina are directly responsible for altering the rainfall. Despite the extreme life strategy of these fish, they do not have a large ecological plasticity of adaptation to climate change in velocities that are occurring (Fontana et al., 2003). The current climate models show a $20 \%$ reduction in rainfall in the semiarid region for every decade. This factor will directly influence the annual fish, by diminishing wetlands and preventing the continuation of the life cycle of annual fish. Increases in temperature and changes in rainfall, with the incidence of prolonged drought and reduced rainfall are predicted due to the effects of global warming on climatic conditions and their impacts on the Brazilian semiarid region (Gitay et al., 2002). There could also be an increase in the frequency of occurrence of episodic heavy rainfall associated with global climate change (Trenberth and Jones, 2007).

For the conservation of $H$. antenori and other species of annual fish, management should focus primarily on the integrity of the habitats where they are found, such as, small temporary pools, which in most cases are not considered a priority for conservation.

Several actions should be taken in order to preserve the annual fish, such as banning deforestation and irrational occupation of wetlands adjacent to watercourses of hydrographic basins; check the indiscriminate use of pesticides and agrochemicals, as well as the release of industrial effluents, domestic waste into water courses; insist on the compliance with the laws protecting the environment, land use and construction of reservoirs on rivers, with priority to those areas where there is presence of annual fish. These measures are essential for the conservation of $H$. antenori and other species of annual fish of Brazilian semiarid region.

\section{Acknowledgements}

Thanks are due to the National Council for Scientific and Technological Development of the Ministry of Science and Technology of Brazil (CNPq/ MCT) for the Research grants offered to the authors, and to the Post-Graduate Federal Agency CAPES/MEC, Brazil. Ours thanks are due to Dr. Wilson Costa of the Department of the Zoology, Universidade Federal do Rio de Janeiro (UFRJ) for confirmation of the taxonomical identification of the study species.

\section{References}

AGOSTINHO, AA., THOMAZ, SM. and GOMES, LC., 2005. Conservation of the biodiversity of Brazil's inland waters. Conservation Biology, vol. 19, no. 3, p. 646-652. http://dx.doi. org/10.1111/j.1523-1739.2005.00701.x.

ARAÚJO, AS., NASCIMENTO, WS., YAMAMOTO, ME. and CHELLAPPA, S., 2012. Temporal dynamics of reproduction of the neotropical fish, Crenicichla menezesi (Perciformes: Cichlidae). TheScientificWorldJournal, vol. 2012, p. 579051. http://dx.doi. org/10.1100/2012/579051. PMid:22919339

ARENZON, A., PERET, AC. and BOHRER, MBC., 1999. Reproduction of the annual fish Cynopoecilus melanotaenia (Regan, 1912) in a temporary water body in Rio Grande do Sul, Brazil (Cyprinodontiformes, Rivulidae). Hydrobiologia, vol. 411, p. 65-70. http://dx.doi.org/10.1023/A:1003868711295.

BEROIS, N., AREZO, MJ., PAPA, NG. and CLIVIO, GA., 2012. Annual fish: developmental adaptations for an extreme environment. Wiley interdisciplinary reviews. Developmental biology, vol. 1, no. 4, p. 595-602. http://dx.doi.org/10.1002/ wdev.39. PMid:23801535

CACHO, MSRF., CHELLAPA, S. and YAMAMOTO, ME., 2006. Reproductive success and female preference in the amazonian cichlid angel fish, Pterophyllum scalare (Lichtenstein, 1823). Neotropical Ichthyology, vol. 4, no. 1, p. 87-91. http://dx.doi. org/10.1590/S1679-62252006000100009.

CHELLAPPA, NT., BORBA, JM. and ROCHA, O., 2008. Phytoplankton community and physical-chemical characteristics of water in the public reservoir of Cruzeta, RN, Brazil. Brazilian Journal of Biology $=$ Revista Brasileira de Biologia, vol. 68, no. 3, p. 477-494. http://dx.doi.org/10.1590/S1519-69842008000300004. PMid: 18833468

CHELLAPPA, NT., CHELLAPPA, T., LIMA, AKA., MEDEIROS, JL., SOUZA, PVV. and CHELLAPPA, S., 2006. Ecology of freshwater phytoplankton assemblages from a tropical of Northeastern Brazil. International Journal of Lakes \& Rivers, vol. 1 , p. 61-81.

CHELLAPPA, S., BUENO, RMX., CHELLAPPA, T., CHELLAPPA, NT. and ALMEIDA-VAL, VMF., 2009. Reproductive seasonality of the fish fauna and limnoecology of semi-arid Brazilian reservoirs. Limnologica, vol. 39, no. 4, p. 325-329. http://dx.doi. org/10.1016/j.limno.2009.06.003.

CHELLAPPA, S., NASCIMENTO, WS., CHELLAPPA, T. and CHELLAPPA, NT., 2011. Impacts of anthropic factors on native freshwater fish in Brazilian semiarid region. In Dempsey, SP. (Eds.). Fish Ecology. 1st ed. New York: Nova Science Publishers, p. 115-130. Marine Biology Seies. 
COSTA, WJEM., 2002. Peixes anuais brasileiros. Curitiba: Editora UFPR.

COSTA, WJEM., 2006. Taxonomic revision of the seasonal South American killifish genus Simpsonichthys (Teleostei: Cyprinodontiformes: Aplocheiloidei: Rivulidae). Zootaxa, vol. 1227, p. 31-55.

COSTA, WJEM., 2008. Catalog of aplocheiloid killifishes of the word. Rio de Janeiro: Reproarte.

COSTA, WJEM., 2011. Phylogenetic position and taxonomic status of Anablepsoides, Atlantirivulus, Cynodonichthys, Laimosemion and Melanorivulus (Cyprinodontiformes: Rivulidae). Ichthyological Exploration of Freshwaters, vol. 22, p. 333-349.

COSTA, WJEM., 2012. Delimiting priorities while biodiversity is lost: Rio's seasonal killifishes on the edge of survival. Biodiversity and Conservation, vol. 21, no. 10, p. 2443-2452. http://dx.doi. org/10.1007/s10531-012-0301-7.

ERREA, A. and DANULAT, E., 2001. Growth of the annual fish, Cynolebias viarius (Cyprinodontiformes), in the natural habitat compared to laboratory conditions. Environmental Biology of Fishes, vol. 61, no. 3, p. 261-268. http://dx.doi. org/10.1023/A:1011047611009.

FONTANA, CS., BENCKE, GA. and REIS, RE., 2003. Livro vermelho da fauna ameaçada de extinção no Rio Grande do Sul. Porto Alegre: EDIPUCRS.

FRICKE, R. and ESCHMEYER, WN., 2012. A guide to Fish Collections in the Catalog of Fishesdatabase. California Academy of Sciences. Available from: <http://research.calacademy.org/ research/ichthyology/catalog/collections.asp >. Access in: 15 Jan. 2013.

FROESE, R., 2006. Cube law, condition factor and weight-length relationships: history, meta-analysis and recommendations. Journal of Applied Ichthyology, vol. 22, no. 4, p. 241-253. http://dx.doi. org/10.1111/j.1439-0426.2006.00805.x.

GASTON, KJ., 1998. Rarity as double jeopardy. Nature, vol. 394, no. 6690, p. 229-230. http://dx.doi.org/10.1038/28288.

GITAY, H., SUÁREZ, A., WATSON, RT. and DOKKEN, DJ., 2002. Climate change and biodiversity: intergoverment panel on climate change. Intergovernmental Panel on Climate Change. Available from: $<$ https://www.ipcc.ch/pdf/technical-papers/ climate-changes-biodiversity-en.pdf $>$. Access in: 10 Jan. 2013.

JOBLING, M., 2008. Environmental factors and rates of development and growth. In HART, PJ., REYNOLDS. JD. (Eds.). Handbook of fish biology and fisheries. Oxford: Blackwell Publishing. p. 97-122. Fish Biology, vol. 2.

LEAL, IR., SILVA, JMC., TABARELLI, M., LACHER JUNIOR, T., 2005. Mudando o curso da conservação da biodiversidade na Caatinga do nordeste do Brasil. Megadiversidade, vol. 1, no. 1, p. $139-146$.

LEAL, IR., TABARELLI, M. and SILVA, JMC., 2003. Ecologia e conservação da Caatinga. Recife: Editora Universitária UFPE.

LEITE, AVL. and MACHADO, IC., 2010. Reproductive biology of woody species in Caatinga, a dry forest of northeastern Brazil. Journal of Arid Environments, vol. 74, no. 11, p. 1374-1380. http://dx.doi.org/10.1016/j.jaridenv.2010.05.029.

MAGURRAN, AE. and GARCIA, M., 2000. Sex differences in behaviour as an indirect consequence of mating system. Journal of Fish Biology, vol. 57, no. 4, p. 839-857. http://dx.doi. org/10.1111/j.1095-8649.2000.tb02196.x.
MILHOME, MAL., SOUSA, DOB., LIMA, FAF. and NASCIMENTO, RF., 2009. Assessment of surface and groundwater potential contamination by agricultural pesticides applied in the region of Baixo Jaguaribe, CE, Brazil. Engenharia Sanitaria Ambiental, vol. 14, p. 363-372.

NASCIMENTO, WS., ARAÚJO, AS., CHELLAPPA, NT. and CHELLAPPA, S., 2012. Reproductive strategy of Leporinus piau (Fowler, 1941) a Neotropical freshwater fish from the semiarid region of Brazil. Journal of Applied Ichthyology, vol. 29, no. 4, p. 877-880. http://dx.doi.org/10.1111/jai.12020.

NASCIMENTO, WS., ARAÚJO, AS., GURGEL, LL., YAMAMOTO, ME., CHELLAPPA, NT., ROSA, RS. and CHELLAPPA, S., 2011. Endemic fish communities and environmental variables of the Piranhas-Assu hydrographic basin in the Brazilian Caatinga Ecoregion. Animal Biology Journal, vol. 2, p. 97-112.

PARAHYBA, RER., CAVALCANTI, VMM., MEDEIROS, MF., 2000. Projeto TECMO-Tecnologia em cerâmica. Ações para a modernidade e competitividade. Fortaleza: DNPM. Atividades $11,12,13,14,15$

PINHEIRO, FSA., 2002. Impactos da extração de argila na planície aluvial do rio Jaguaribe. Fortaleza: Universidade Federal do Ceará. Masters Dissertation.

REIS, RE., KULLANDER, SO. and FERRARI JUNIOR, CJ., 2003. Check list of the freshwater fishes of South and Central America. Porto Alegre: EDPUCRS.

ROSA, RS. and LIMA, FCT., 2008. Peixes. In MACHADO, ABM., DRUMMOND, GM. and PAGLIA, AP. (Eds.). Livro vermelho da fauna brasileira ameaçada de extinção. Brasília: Ministério do Meio Ambiente.

ROSA, RS., MENEZES, NA., BRITSKI, HÁ., COSTA, WJEM. and GROTH, F., 2005. Diversidade, padrões de distribuição e conservação dos peixes da Caatinga. In LEAL, IR., TABARELLI, M. and SILVA, JMC. (Eds.). Ecologia e Conservação da Caatinga. Recife: Editora UFPE. p. 135-180.

SFAKIANAKIS, DG., LERIS, I., MYLONAS, CC. and KENTOURI, M., 2012. Temperature during early life determines sex in zebrafish, Danio rerio (Hamilton, 1822). Journal of Biological Research, vol. 17 , p. $68-73$.

SHANG, EH., YU, RM. and WU, RSS., 2006. Hypoxia affects sex differentiation and development, leading to a male-dominated population in zebrafish (Danio rerio). Environmental Science \& Technology, vol. 40, no. 9, p. 3118-3122. http://dx.doi.org/10.1021/ es0522579. PMid:16719120

SHIBATTA, AO., 2006. Social behavior of pirá-brasília, Simpsonichthys boitonei Carvalho, 1959 (Cyprinodontiformes, Rivulidae). Revista Brasileira de Zoologia, vol. 23, no. 2, p. 375-380. http://dx.doi.org/10.1590/S0101-81752006000200010.

SILVA, VPR., 2004. On climate variability in Northeast of Brazil. Journal of Arid Environments, vol. 58, no. 4, p. 575-596. http:// dx.doi.org/10.1016/j.jaridenv.2003.12.002.

TRENBERTH, KE. and JONES, PD., 2007. Observations: Surface and atmospheric climate change. In SOLOMON, S., QIN, D., MANNING, M., MARQUIS, M., AVERYT, K., TIGNOR, MMB., MILLER JUNIOR, KL. and CHEN, Z. (Eds.). Climate change 2007: the physical science basis. Contribution of working group i to the Fourth Assessment Report of the Intergovernmental Panel on Climate Change. Cambridge: Cambridge University Press. p. 235-336 
VOLCAN, VM., GONÇALVES, AC. and LANÉS, LEK., 2011. Distribution, habitat and conservation status of two threatened annual fishes (Rivulidae) from southern Brazil. Endangered Species Research, vol. 13, no. 2, p. 79-85. http://dx.doi.org/10.3354/esr00316.

World Meteorological Organization - WMO, 2012. Provisional Statement on the State of Global Climate in 2012. Embargo 1130 gmt (1430 doha). Geneva: WMO.
WOURMS, JP., 1972. The developmental biology of annual fishes. 3. Pre-embryonic and embryonic diapause of variable duration in the eggs of annual fishes. The Journal of Experimental Zoology, vol. 182, no. 3, p. 389-414. http://dx.doi.org/10.1002/ jez.1401820310. PMid:4674089

WU, RSS., 2009. Effects of hypoxia on fish reproduction and development. In RICHARDS, JG., FARRELL, AP. and BRAUNER, CJ. (Eds.). Fish Physiology. Amsterdã: ELSEVIER. p. 79-141 